\title{
FLORISTIC COMPOSITION OF BLACK PINE FORESTS ON SERPENTINITE IN THE TERRITORY OF SERBIA AND BOSNIA AND HERZEGOVINA (B\&H)
}

\author{
NOVAKOVIĆ-VuKOVIĆ, M. ${ }^{1 *}$ - EREMIJA, S. $^{2}$ - LUČIĆ, A. ${ }^{2}$ - HADROVIĆ, S. ${ }^{2}$ - KAPOVIĆ \\ SOLOMUN, M. ${ }^{3}$ - BlAGOJEVIĆ, V. ${ }^{4}-$ KOŠANIN, O. ${ }^{1}$ \\ ${ }^{1}$ Faculty of Forestry, University of Belgrade, 11000 Belgrade, Serbia \\ (e-mail/phone: olivera.kosanin@sfb.bg.ac.rs/+381-11-305-3975) \\ ${ }^{2}$ Institute of Forestry, 11000 Belgrade, Serbia \\ (e-mail/phone: sasaeremija@gmail.com/+381-69-816-0090; \\ aleksandar.lucic@gmail.com/+381-63-841-3101; hadrovicsabahudin@gmail.com/+381-63- \\ 833-2202) \\ ${ }^{3}$ Faculty of Forestry, University of Banja Luka, 78000 Banja Luka, B\&H \\ (e-mail/phone: marijana.kapovic-solomun@ sf.unibl.org/+387-65-912-396) \\ ${ }^{4}$ Public Company "Šume Republike Srpske", a. d. Sokolac, 78000 Banja Luka, B\&H \\ (e-mail/phone:velibor_blagojevic@yahoo.com/+387-65-627-471) \\ *Corresponding author \\ e-mail: marijana.novakovic@sfb.bg.ac.rs; phone: +381-11-305-3975
}

(Received $10^{\text {th }}$ Dec 2018; accepted $27^{\text {th }}$ Feb 2019)

\begin{abstract}
Black pine forests of the Western Balkans constitute a significant complex of azonally and orographically-edaphically conditioned forests, on the ophiolite massifs of central and eastern Bosnia, as well as western and, to a certain extent, central Serbia. CA and Cluster analysis showed that there was no overlap in the floristic composition, which means that there are significant differences between the studied stands. Stands in Bosnia and Herzegovina (B\&H) are floristically richer with 152 taxa recorded, while stands in Serbia had 82 taxa recorded. On the territory of B\&H, communities grow under the conditions of maritime and humid climate; while in Serbia they grow in continental climate with less rainfall and significant exposure to sub-Mediterranean weather. In black pine forests in $\mathrm{B} \& \mathrm{H}$ two types of soil were described: eutric humus-siliceous, and brown soil on serpentinite; while in Serbia, there was only one type - eutric humus-siliceous. No significant differences were found in the spectrum of life forms. In the spectrum of floral elements, mesophilic floral elements (Central and Sub-Atlantic) were dominant on the territory of $\mathrm{B} \& \mathrm{H}$; while stands in Serbia, were richer in xerophilous floral elements (Mediterranean, Balkan, Balkan-Apennine). Shannon-Wiener index and evenness index showed higher values in $\mathrm{B} \& \mathrm{H}$.
\end{abstract}

Keywords: Balkan, Pinus nigra, forest plant communities, floristic similarity, phytosociology

\section{Introduction}

Area of Southern Europe, Iberian, Apennine and the Balkan Peninsula, along with the Crimea, Anatolia and the Caucasus mountains, is generally accepted as a refuge area, within which many tree species managed to survive during the glacial and postglacial periods (Hewitt, 1999; Jasińska et al., 2014). Balkan Peninsula was one of the most significant refuge areas in Europe, because it had a warmer climate due to its geographical position, thus the glaciation was not fully expressed. This especially pertains to the western parts of the peninsula, where temperature changes during the glaciation were relatively small (Bennett et al., 1991). The plant cover of serpentinite is 
a segment of flora and vegetation of the Balkan Peninsula extremely rich in species, many of which are endemic. Serpentinite has a high percentage of $\mathrm{Mg}(18-24 \%), \mathrm{Fe}$ (69\%) and heavy metals (Ni, $\mathrm{Co}, \mathrm{Cr}, \mathrm{Mn})$, but a low content of $\mathrm{Ca}(1-4 \%)$, and $\mathrm{Al}(1-2 \%)$ (Alexander, 2004). Soils formed on ultramafic rock, which includes serpentinite, can contain several hundred times more nickel (Ni), an element toxic to plants (Altinözlü et al., 2012), than other soils. Soils on serpentinites have unfavorable chemical composition, are shallow, rocky, often formed on steep slopes, so they are unsuitable for most plants and represent a stressful environment for their growth (Kazakou et al., 2008).

On the Balkan Peninsula, on serpentine bedrock, population of black pine occupies a significant area. Black pine (Pinus nigra Arn.) belongs to the group of Mediterranean pines, has a disjunct range and is present in North Africa, western Europe (Spain), running across the northern Mediterranean and to the Black Sea on the east (Afzal-Rafii and Dodd, 2007; Rubio-Moraga et al., 2012). Black pine is a typical South European forest tree species that is ecologically and economically important in a very wide distribution area (Gülsoy and Çinar, 2019). Black pine forests in the area of the Balkan Peninsula occupy different geological substrates. They represent a significant complex of azonallly and orographically-edaphically conditioned forests on the ophiolite massifs of central and eastern Bosnia and western and central Serbia. Many authors consider this forest a relic due to a dominant role of black pine (Pinus nigra subsp. gocensis Vid.), which is, along with disjunctive areas of some subspecies, a typical tertiary relic (Tatić and Tomić, 2006). Black pine forests on the serpentines are highly dynamical systems, and their development goes in two directions: towards sessile forests at low altitudes, and towards the beech-fir forests at higher altitudes (Jović and Tomić, 1985). The aim of the paper was to broaden the knowledge on the black pine forests on serpentine bedrock and to compare the floristic data in order to determine the differences between the studied forests in the territory of Serbia and B\&H.

\section{Material and methods}

\section{Study area}

Research included natural stands of black pine on serpentine bedrock in Serbia and B\&H (Fig. 1). Figure 2 illustrate the habitat of studied stands. Black pine stands in the area of the $\mathrm{B} \& \mathrm{H}$ are described in three locations (Table 1): Dobojsko-Derventski (DD) and Usorsko-Ukrinski (UU), which belong to the Central Bosnian ophiolite range, as well as in the area of Višegrad (V), which is located in eastern B\&H. The average value of precipitation in Višegrad, at $416 \mathrm{~m}$ a.s.1. is $738 \mathrm{~mm}$, and in Doboj, at $147 \mathrm{~m}$ a.s.l. it is $972 \mathrm{~mm}$.

Black pine stands in Serbia are described in Pešter (P), in southwestern Serbia, as well as on Kopaonik (K), which is located in central Serbia. On Pešter, at 1038 m a.s.1, the average value of precipitation is $712 \mathrm{~mm}$, and on Kopaonik, at $1097 \mathrm{~m}$ a.s.l, it is $885 \mathrm{~mm}$.

\section{Field work and data analysis}

The study of floristic composition of the investigated stands was based on a total of 28 phytocoenological relevés. They were made by the classical method of ZurichMontpellier school of phytosociology (Braun-Blanquet, 1964) and they are taken from 
literature. 15 relevés (Novaković-Vuković, 2015) were sampled in the black pine forest on serpentinites of Pešter $(\mathrm{P})$ and Kopaonik $(\mathrm{K})$ - Serbia, and 13 relevés, also in the black pine forest, were recorded on serpentines of Višegrad (V), Doboj-Derventa (DD) and Usorsko-Ukrinska (UU) area - B\&H (Blagojević, 2016). Field research was carried out in the period from 2009 to 2011 in Serbia and in the period from 2013 to 2015 in B\&H. Syntaxonomic names were given according to Tomić and Rakonjac (2013). Spectra of floral elements were performed based on the systematization of phytogeographical elements (Gajić, 1980); floral elements that were not found in this source were supplemented according to Stevanović (1992) and Oberdorfer (2001). The spectrum of life forms, which is based on the division of Raunkiaer (1934), was determined according to Kojić et al. (1997), and partially according to MuellerDombois and Ellenberg (1974).

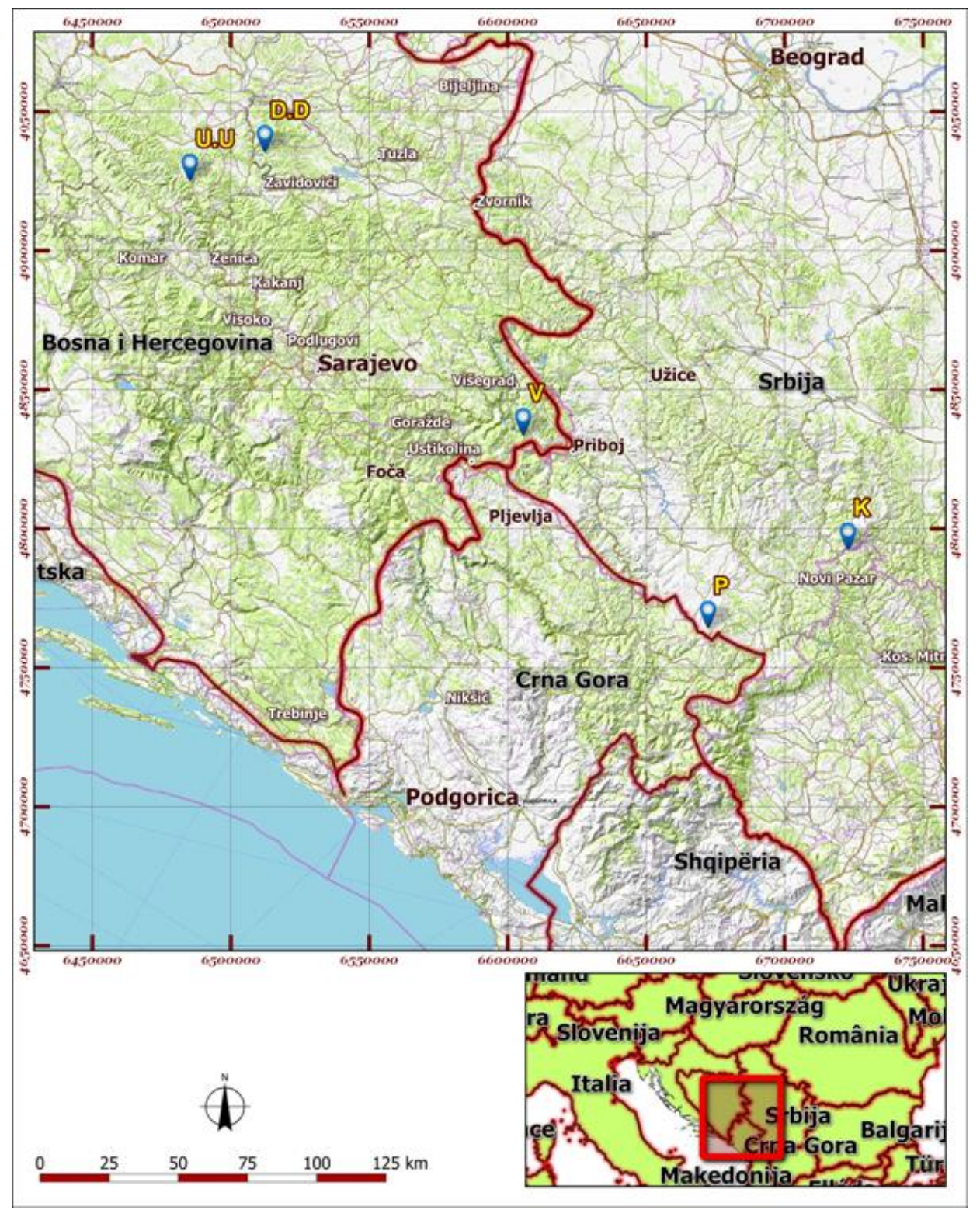

Figure 1. Location of studied stands in Serbia and B\&H. (Abbreviations for locations: DD Dobojsko-Derventski, UU - Usorsko-Ukrinski, V - Višegrad - B\&H; P - Pešter, K - KopaonikSerbia) 


$$
-5002-
$$

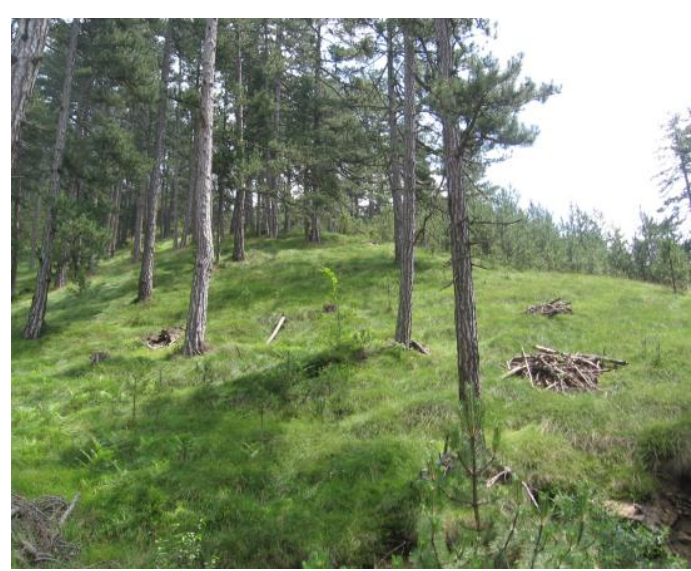

a

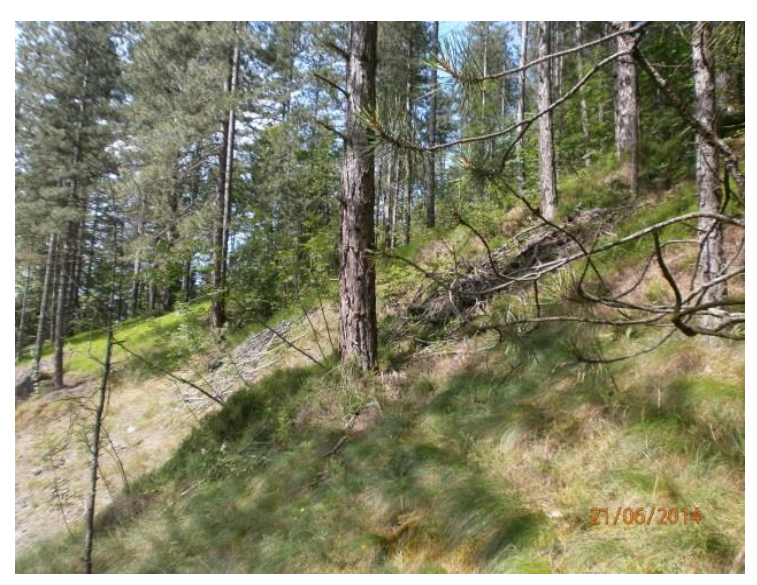

b

Figure 2. The habitat of Black pine: a) Serbia, Kopaonik (K) and b) $B \& H$, DobojskoDerventsko $(D D$ 入

Table 1. GPS coordinates of phytocoenological relevés

\begin{tabular}{|c|c|c|}
\hline Relevé number & $\begin{array}{c}\text { Gauss-Kruger } \\
\text { X }\end{array}$ & $\begin{array}{c}\text { Gauss-Kruger } \\
\text { Y }\end{array}$ \\
\hline K_1 & 7490309 & 4781855 \\
\hline K_2 & 7490091 & 4782456 \\
\hline K_3 & 7490069 & 4782599 \\
\hline K_4 & 7489989 & 4782850 \\
\hline K_5 & 7489926 & 4782856 \\
\hline$P \_1$ & 7408023 & 4783187 \\
\hline P_2 & 7407951 & 4783197 \\
\hline P_3 & 7407965 & 4783214 \\
\hline$P_{-} 4$ & 7407934 & 4783296 \\
\hline P_5 & 7407902 & 4783284 \\
\hline P_6 & 7407909 & 4783305 \\
\hline$P_{-} 7$ & 7407930 & 4783331 \\
\hline P_8 & 7407947 & 4783259 \\
\hline P_9 & 7407963 & 4783249 \\
\hline P_10 & 7408040 & 4783140 \\
\hline$V_{-} 1$ & 6599825 & 4857465 \\
\hline V_2 & 6604813 & 4856663 \\
\hline V_3 & 6600031 & 4858201 \\
\hline DD_1 & 6519554 & 4945626 \\
\hline DD_2 & 6519753 & 4945105 \\
\hline DD_3 & 6518250 & 4946100 \\
\hline UU_1 & 6477630 & 4935730 \\
\hline UU_2 & 6477770 & 4935723 \\
\hline DD_4 & 6517036 & 4945859 \\
\hline DD_5 & 6519300 & 4945550 \\
\hline UU_3 & 6477203 & 4936263 \\
\hline V_4 & 6599073 & 4857122 \\
\hline
\end{tabular}

Abbreviations for locations: DD - Dobojsko-Derventski, UU - Usorsko-Ukrinski, V - Višegrad - B\&H; P - Pešter, K - Kopaonik - Serbia 
In order to determine the similarity in the floristic composition between the studied stands, Bray-Curtis cluster analysis (measuring similarity) with the option "Group Average" in BIODIVERSITY PRO (McAleece et al., 1997) was performed. DCA vegetation data analysis was performed using the statistical software CANOCO 4.5 (Lepš and Šmilauer, 1999). The cover-abundance score obtained for each species within a relevé was transformed using the method of Van Der Maarel (Van Der Maarel, 1979). Indices of diversity and evenness (Shannon-Wiener diversity index and Evenness) were calculated using the program JUICE 7.0.166 (Tichý, 2002).

Shannon-Wiener diversity index is a mathematical measure of species diversity in a community. It is derived from a formula:

$$
\mathrm{H}^{\prime}=-\sum p i \ln p i \mathrm{pi}=\mathrm{ni} / \mathrm{N}
$$

where "N" represents total species count, and "ni" ground coverage of $i$-species.

Species evenness shows how close in numerical values each species in an environment is. Species evenness index is calculated using the formula (Pielou, 1975):

$$
\mathrm{EH}=\mathrm{H}^{\prime} / \mathrm{H}^{\prime} \max =\mathrm{H}^{\prime} / \operatorname{lnN} \text {, }
$$

where "N" is number of species (taxa) in a phitocenological sample.

$\mathrm{E}_{\mathrm{H}}$ ranges between 0 and 1 . Lower evenness between species in a community (and presence of dominant species) will result in lower $\mathrm{E}_{\mathrm{H}}$ letter.

\section{Results}

The black pine stands in the Višegrad, Dobojsko-Derventska and Usorsko-Ukrinska area $(\mathrm{B} \& \mathrm{H})$ were recorded at the altitudes ranging between 293 and $590 \mathrm{~m}$ and all aspects, but preferably at warmer ones (S, SW). The community grows on slopes of varying steepness; it has been recorded on flat ground or on a very mild slope $\left(2^{\circ}\right)$, but the majority of stands have been recorded on very steep slopes $\left(25-33^{\circ}\right)$. At all three sites, stands of black pine were situated on two types of soil: eutric humus siliceous and brown soil on serpentinite. There were 152 taxa recorded in 13 phytocoenological relevés. For a complete inventory see Appendix.

Stands on Pešter and Kopaonik (SRB) were located at the altitude of between 900 and $1219 \mathrm{~m}$, where stands on the Kopaoniku are located at altitudes between 900 and 963 m, while stands on Pešter occupy narrow range of altitudes between 1180 and 1219 m. Stands of black pine on Kopaonik occupy mainly western aspects (NW, SW), while stands on Pešter occupy various aspects, but more often cooler ones (N, E, NE). Common to both sites is that slopes are steep to very steep $\left(20-35^{\circ}\right)$. There were 82 taxa recorded in 15 phytocoenological relevés. Black pine stands in Serbia were recorded on one type of soil, eutric humus siliceous, provided that on Kopaonik it is medium skeletal eutric humus siliceous on serpentinite, while on Pešter it is colluvial eutric humus siliceous soil.

High floristic similarity of studied stands is visible on the graph (Fig. 3), which was expected because in both cases the pine forests grow on serpentine bedrock. However, it is notable that studied stands make two separate groups: relevés from Serbia are concentrated along the $\mathrm{y}$-axis, relevés from $\mathrm{B} \& \mathrm{H}$ show greater dispersion along the $\mathrm{x}$ axis. The graph shows following mutual species as isolated: Pinus nigra, cinquefoil 
(Potentilla heptaphylla), deutscher backenklee (Dorycnium germanicum), wood false brome (Brachypodium sylvaticum). Within relevés from Serbia, xerophilous species of the Erico-Pinetalia order: burnet rose (Rosa spinosissima), ironwort (Stachys scardica), Balkan daphne (Daphne blagayana), rabbit tail (Sesleria serbica), Pinus nigra, owlhead clover (Trifolium alpestre), etc. appear as isolated. Within relevés from B\&H, species of wide ecological amplitude: common bracken (Pteridium aquilinum), Festuca rupicola, bird's-foot trefoil (Lotus corniculatus), wild strawberry (Fragaria vesca), mountain melick (Melica nutans) etc. appear as isolated, as well as some mesophilous species: tuberous comfrey (Symphytum tuberosum), sessile oak (Quercus petraea), blackberry (Rubus hirtus). The presence of mesophilous species and species of wider ecological amplitude in the black pine forests in the area of $\mathrm{B} \& \mathrm{H}$ indicates more mesophilous conditions within these forests in the Illyrian province. It should be noted that beech in Serbia is described as Fagus moesiaca, whereas in B\&H it is described as Fagus sylvatica. Sessile oak is also treated dually, in Serbia as Balkan oak (Quercus dalechampii), in B\&H as Quercus petraea, which slightly affected the arrangement of phytocoenological relevés in the coordinate system.

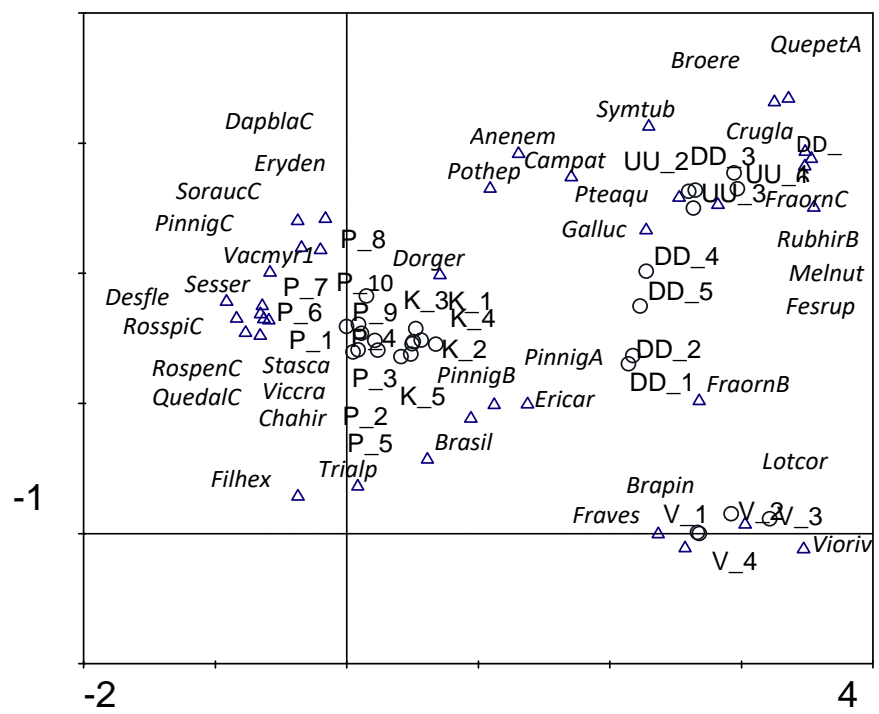

Figure 3. DCA ordination bi-plot, fit range for species 30-100\%, 38 species ( - - relevé representation, $\triangle$ - species representation). (Abbreviations for locations: DD - DobojskoDerventski, UU - Usorsko-Ukrinski, V-Višegrad - B\&H; P - Pešter, K - Kopaonik-Serbia. Abbreviations for species: Quepet-Quercus petraea; Broere-Bromus erectus; SymtubSymphytum tuberosum; Dapbla-Daphne blagayana; Anenem-Anemone nemorosa; CruglaCruciata glabra; Campat-Campanula patula; Eryden-Erythronium dens canis; PothepPotentilla heptaphylla; Sorauc-Sorbus aucuparia; Pteaqu-Pteridium aquilinum; FraornFraxinus ornus; Pinnig-Pinus nigra; Vacmyr-Vaccinium myrtillus; Dorger-Dorycnium germanicum; Rubhir-Rubus hirtus; Sesser-Sesleria serbica; Melnut-Melica nutans; FesrupFestuca rupicola; Desfle-Deschampsia flexuosa; Rosspi-Rosa spinosissima; Rospen-Rosa pendulina; Stasca-Stachys scardica; Quedal-Quercus dalechampii; Viccra-Vicia cracca; Chahir-Chamaecytisus hirsutus; Filhex-Filipendula hexapetalla; Triapl-Trifolium alpeste; Ericar-Erica carnea; Brasil-Brachypodium silvaticum; Brapin-Brachypodium pinnatum; Lotcor-Lotus corniculatus; Fraves-Fragaria vesca; Vioriv-Viola riviniana. The abbreviation following the species denotes A - tree layer, B - shrub layer, $C$ - ground flora layer) 
Cluster analysis (Fig. 4) also showed that studied stands compose two separate groups: one group includes phytocoenological relevés from Serbia and the other group includes phytocoenological relevés from $\mathrm{B} \& \mathrm{H}$. There is no overlapping between the studied stands of two countries, which suggests that there is clear floristic differentiation between them.

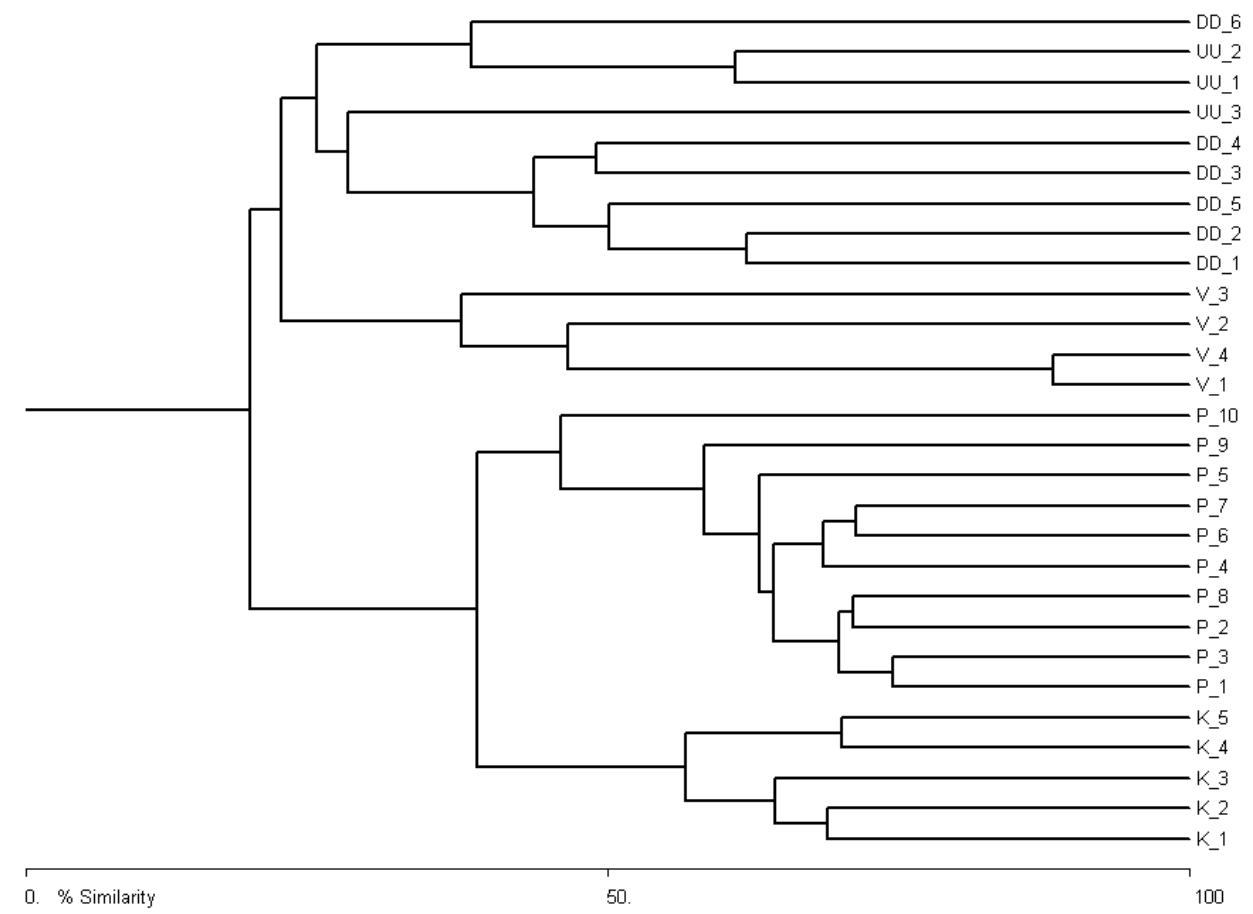

Figure 4. Cluster analysis of studied stands of black pine in Serbia and B\&H. (Abbreviations for locations: DD - Dobojsko-Derventski, UU - Usorsko-Ukrinski, V-Višegrad - B\&H; P Pešter, $K$ - Kopaonik - Serbia)

In the spectrum of life forms no significant differences between two countries (Table 2) were observed. Hemicryptophytes are a dominant life form in both Serbia and $\mathrm{B} \& \mathrm{H}$, with nearly equal representation. Phanerophytes are slightly more numerous in Serbia than in B\&H (22\% to $15.8 \%$ ), while chamaephytes are more common in $\mathrm{B} \& \mathrm{H}$ than in Serbia (15.7\% to $12.2 \%$ ). Other life forms are almost evenly represented.

Table 2. Spectrum of life forms in the black pine forest in Serbia and $B \& H$

\begin{tabular}{c|c|c}
\hline Life form & Serbia & B\&H \\
\hline Phanerophytes & $22 \%$ & $15.80 \%$ \\
Chamaephytes & $12.20 \%$ & $15.70 \%$ \\
Hemicryptophytes & $50 \%$ & $53.30 \%$ \\
Geophytes & $12.20 \%$ & $11.20 \%$ \\
Therophytes & $1.20 \%$ & $0.70 \%$ \\
Lianas & $0.00 \%$ & $0.70 \%$ \\
Therophytes/chamaephytes & $2 \%$ & $2.60 \%$ \\
\hline
\end{tabular}


In the spectrum of floral elements (Fig. 5) more significant differences were observed, in comparison to the spectrum of life forms. In the spectrum of floral elements, the collective group of Central-European floral elements is dominant in both countires, with larger abundance in B\&H than in Serbia (27\%: 22\%). A high presence of this group of floral elements indicates syndinamic connection between xerophilous black pine forest with more mesophilous sessile oak and beech forest. It is followed by a group of species of broad ecological amplitude of the Eurasian distribution type, with equal presence in both countries. If more xerophilous floral elements are observed separately (Sub-Mediterranean, Balkan, Balkan-Apeninian), it is noted that their presence is significantly higher in Serbia than on the territory of B\&H (24.5\% to $19 \%)$. The largest presence of sub-Mediterranean floral element is on Kopaonik (Serbia), as a result of exposure of this mountain massif to sub-Mediterranean. On the other hand, the mesophilous floral elements (Central-European and Subatlantic) are more numerous in B\&H than in Serbia (31.6\% to $24.4 \%$ ). Greater presence of mesophilous floral elements in $\mathrm{B} \& \mathrm{H}$ and xerophilous in Serbia is a consequence of, first of all, different climatic influences - higher humidity in Illyrian province, to which study stands in the B\&H belong.

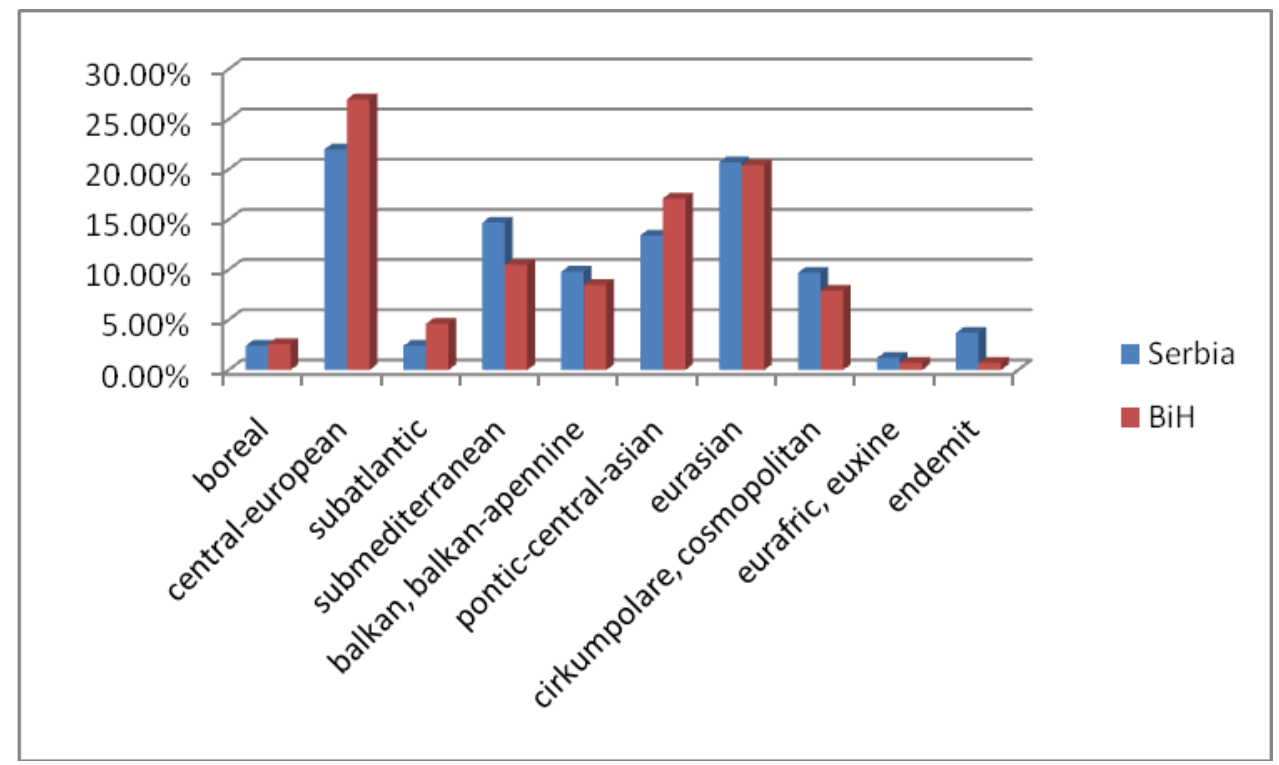

Figure 5. The spectrum of floral elements in the black pine forest in Serbia and $B \& H$

For diversity analysis (Table 3) Shannon-Wiener diversity index of ground flora was used, which is sensitive to rare species (Heuserr, 1998). Diversity index (ShannonWiener index) shows higher value in B\&H than in Serbia, which was expected, because the black pine stands in B\&H have more species per phytocoenological relevé. Evenness index also shows higher value in $\mathrm{B} \& \mathrm{H}$, where the spatial distribution of species is more regular than in Serbia, given that the index value approaches the number 1. Species winter heath (Erica carnea), Brachypodium silvaticum, bilberry (Vaccinium myrtillus), Sesleria serbica, may be denoted as species that reduce the Evenness index value in Serbia, considering their number and coverage; while in B\&H these are Erica carnea, heath false brome (Brachypodium pinnatum), Pteridium aquilinum, erect brome (Bromus erectus), etc. 
Table 3. Indices of diversity and evenness in researched stands

\begin{tabular}{c|c|c}
\hline Locality & Average Shannon-Wiener index & Average Evenness index \\
\hline Serbia & 2.35 & 0.64 \\
B\&H & 2.57 & 0.74 \\
\hline
\end{tabular}

\section{Discussion}

Black pine is one of the main important tree species in the Mediterranean region, but, this species is also tolerant to cold temperatures and can occur at higher elevations of up to $1800 \mathrm{~m}$ a.s.l. (Kara and Topacoglu, 2018). Although the observed stands in Serbia and $\mathrm{B} \& \mathrm{H}$ are located at different elevations, distribution of pine forest types is not primarily determined by elevation, but rather by relief, exposure, slope, character of the soil, as well as exposure to the winds (Pavlović, 1951). Since black pine stands on the territory of B\&H belong to the Illyrian province, and stands in Serbia to Moesian and transitional Illyrian-Moesian province, significant differences in floristic composition are observed between them. Illyrian province is characterized by significantly higher amount of precipitation, compared to Moesian province, so ti is considered more humid. On the other hand, Moesian province climate is more continental: average temperature differences between summer and winter are more extreme, yearly amounts of precipitate are lower, and summer heats are followed by the lowest amounts of water residues. Generally speaking, Moesian vegetation, compared to Illyric, is much more xerotermophillic, and notably more resistant to high summer temperatures and drought (Jankovic, 1984). Of course, besides the macroclimate, microclimate also exhibits impact on vegetation. The elements of microclimate are interdependent, so that the changes in one of the elements affect other elements. The intensity of the trend of these changes depend on the type of forest, its structure, geographical location, canopy closure and other features (Babić et al., 2015).

The main characteristic of black pine forests on serpentine is presence of winter heath (Erica carnea), which the whole class of pine forests is named after (EricoPinetea Ht. 1959). Erica carnea has Illyrian geographical distribution, so the climate of Kopaonik (Serbia) does not suit it, hence this species was recorded in low numbers and coverage in this locality. In the area of $\mathrm{B} \& \mathrm{H}$ in 4 phytocoenological relevés typical Illyrian species alpine barrenwort (Epimedium alpinum) was recorded, with its presence decreasing going from the west towards the east, so it was not recorded in relevés in Serbia. Regular satelite of pine forests of Kopaonik (Serbia) is prickly juniper (Juniperus oxycedrus), representative of sub-Mediterranean flora, which was not recorded in stands of $\mathrm{B} \& \mathrm{H}$, as another evidence of xerophillity of studied stands. Although these pine forests are on ultrabasic bedrock, in the floristic composition, two noticably acidophilous species stand out with their abundance and coverage: Vaccinium myrtillus in Serbia and common heather (Calluna vulgaris) in B\&H. This phenomenon is a result of bases from the soil having been washed out due to the high amount of precipitation that led to acidification. This applies in particular to the species Calluna vulgaris, which belongs to the Atlantic areal type and its presence is, as expected, greatest in western and northern Europe, and decreases going towards the east. In the area of ex Yugoslavia, this species has the largest presence in Slovenia and Croatia, somewhat less in the $\mathrm{B} \& \mathrm{H}$, and it is recorded at only four locations in Serbia (Cvjetićanin et al., 2014). Serpentine bedrock has low number of species compared to 
limestone (Ritter-Studnička, 1963; Brković et al., 2015), but is rich in endemic and relic species. Following species were recorded in studied stands as relic: Pinus nigra, European hop-hornbeam (Ostrya carpinifolia), mahaleb cherry (Cerasus mahaleb), Cardamine glauca and spurge (Euphorbia glabriflora). According to Stevanović et al. (2003), following endemics within studied forests of black pine in Serbia were recorded: Allysum markgrafii, Sesleria serbica, Crocus veluchensis, Stachys scardica, Euphorbia glabriflora and Melampyrum hoermannianum; while on the territory of B\&H Thymus jankae is present as an endemic species, and Scabiosa leucophylla as a sub-endemic species. Black pine stands in Serbia are poorer in floristic composition in comparison to stands in $\mathrm{B} \& \mathrm{H}$. The explanation might be that in terms of the continental climate on Pešter (Serbia), where winters are long and cold and vegetation period is short, only those species within the black pine forest that had adapted to extreme temperature conditions have survived. On Kopaonik (Serbia) there is a strong influence of the Mediterranean, so stands of black pine contain largest number of subMediterranean species and chamaephytes, because these species are able to withstand the harsh life conditions. Clyster analysis of beech forests of SE Europe also showed that there was a significant increase in the proportion of Stenomediterranean, Eurymediterranean, Mediterranean-Montane, and Eurasian species, while Boreal species, decreased toward the southeast (Marinšek et al., 2013). Ritter-Studnička (1963) came to conclusions about the presence of individual life forms studying the serpentine complex in Bosnia, where decreasing presence of chamaephytes with increasing mesophilous conditions is observed, while geophytes are equally present on both bare substrate and in mesophilic conditions. Slopes are generally steeper than at other sites, soils are more skeletal and shallower, exposures are warmer, mainly west and southwest, all of which have an effect on poorer floristic composition. On the other hand, stands of black pine in B\&H grow in more humid conditions, have developed soils, mild slopes, lower altitudes, and therefore living conditions are more favorable. The study of transition from warm to mesic forest vegetation showed that the model based on all variables has the best explanatory power and it is followed by models based on groups of variables, as: ecology, chorotypes, geomorphology, structure and function and soil properties (Čarni et al., 2016).

\section{Conclusion}

Comparison of floristic characteristics of Black pine forests on the territories of Serbia and B\&H was conducted. Stands in B\&H are floristically richer with 152 taxa recorded, while stands in Serbia had 82 taxa recorded. In the spectrum of floral elements, mesophilic floral elements (Central and Sub-Atlantic) were dominant on the territory of $\mathrm{B} \& \mathrm{H}$, while stands in Serbia were richer in xerophilous floral elements (Mediterranean, Balkan, Balkan-Apennine). Results indicate the need for further research of flora and vegetation of the aforementioned localities. Multidisciplinary research, especially monitoring microclimate characteristics of these territories, could provide explanation for the distribution of certain plant species, as well as forest phytocenoses of researched territories. 


\section{REFERENCES}

[1] Afzal-Rafii, Z., Dodd, R. S. (2007): Chloroplast DNA supports a hypothesis of glacial refugia over postglacial recolonization in disjunct populations of black pine (Pinus nigra) in Western Europe. - Molecular Ecology 16: 723-736.

[2] Alexander, E. B. (2004): Serpentine soil redness, differences among peridotite and serpentinite materials, Klamath Mountains, California. - International Geology Review 46(8): 754-764.

[3] Altinözlü, H., Karagöz, A., Polat, T., Ünver, I. (2012): Nickel hyperaccumulation by natural plants in Turkish serpentine soils. - Turkish Journal of Botany 36: 269-280.

[4] Babić, V., Krstić, M., Govedar, Z., Todorić, J., Vuković, N., Milošević, Z. (2015): Temperature and other microclimate conditions in the oak forests on Fruška Gora (Serbia). - Thermal Science 19(suppl. 2): S415-S425.

[5] Bennett, K. D., Tzedakis, P. C., Willis, K. J. (1991): Quaternary refugia of North European trees. - Journal of Biogeography 18: 103-115.

[6] Blagojević, V. (2016): Edaphic characteristics and types Austrian pine forests in the Republic of Srpska. - PhD Thesis, University of Belgrade, Faculty of Forestry, Belgrade, Serbia.

[7] Braun-Blanquet, J. (1964): Pflanzensoziologie, Grundzüge der Vegetationskunde. 3rd Ed. - Springer, Wien.

[8] Brković, D., Tomović, G., Niketić, M., Lakušić, D. (2015): Diversity analysis of serpentine and non-serpentine flora-or, is serpentinite inhabited by a smaller number of species compared to different rock types? - Biologia 70(1): 61-74.

[9] Čarni, A., Matevski, V., Juvan, N., Kostadinovski, M., Košir, P., Marinšek, A., Paušič, A., Šilc, U. (2016): Transition along gradient from warm to mesic temperate forests evaluated by GAMM. - Journal of Plant Ecology 9(4): 421-433.

[10] Cvjetićanin, R,. Košanin, O., Perović, M., Novaković-Vuković, M. (2014): Floristic and edaphic characteristics of the sessil oak and heather forest (Calluno-Quercetum petraeae Schlüter 1959) in the area of mali Zvornik (article in Serbian with an abstract in English). - Šumarstvo 3-4: 63-73.

[11] Gajić, M. (1980): Pregled vrsta flore SR Srbije sa biljnogeografskim oznakama. Glasnik Šumarskog fakulteta 54: 111-141.

[12] Gülsoy, S., Çinar,, T. (2019): The relationships between environmental factors and site index of Anatolian black pine (Pinus nigra Arn. subsp. pallasiana (Lamb.) Holmboe) stands in Demirci (Manisa) district, Turkey. - Applied Ecology and Environmental research 17(1): 1235-1246.

[13] Heuserr, J. J. M. (1998): Putting Diversity Indices into Practice - Some Consideration for Forest. - In: Bachman, P., Köhl, M., Päivinen, R. (eds.) Proceedings of the Conference on Assessment of Biodiversity for Improved Forest Planning. Monte Verità, Switzerland, 711 October 1996. Proceedings No. 18. Kluwer Academic Publishers, London, pp. 171180.

[14] Hewitt, G. M. (1999): Post-glacial re-colonization of European biota. - Biological Journal of Linnean Society 68(1-2): 87-112.

[15] Janković, M. M. (1984): Vegetacija SR Srbije; istorija i opšte karakteristike. - In: Sarić, M. R. (ed.) Vegetacija SR Srbije I. Srpska akademija nauka i umetnosti, Beograd, pp. 1166.

[16] Jasińska, A., Boratyńska, K., Dering, M., Sobierajska, K., Ok, T., Romo, A,. Boratyński, A. (2014): Distance between south-European and south-west Asiatic refugial areas involved morphological differentiation: Pinus sylvestris case study. - Plant Systematics and Evolution 300: 1487-1502.

[17] Jović, N., Tomić, Z. (1985): Kompleks (pojas) termofilnih borovih tipova šuma u Srbiji. - Glasnik Šumarskog fakulteta 64: 9-25. 
[18] Kara, F., Topacoglu, O. (2018): Initial responses of containerized black pine (Pinus nigra Arnold) seedlings to leaf removal prior to out-planting. - Baltic Forestry 24(1): 117-122.

[19] Kazakou, E., Dimitrakopoulus, P. G., Baker, A. J. M., Reeves, R. D., Troumbis, A. Y. (2008): Hypotheses, mechanisms and trade-offs of tolerance and adaptation to serpentine soils: from species to ecosystem level. - Biological Reviews 83: 495-508.

[20] Kojić, M., Popović, R., Karadžić, B. (1997): Vaskularne biljke Srbije. - Institut za istraživanja u poljoprivredi „Srbija“, Beograd.

[21] Lepš, J., Šmilauer, P. (1999): Multivariate Analysis of Ecological Data. - Faculty of Biological Sciences, University of South Bohemia, České Budějovice.

[22] Marinšek, A., Šilc, U., Čarni, A. (2013): Geographical and ecological differentiation of mesophilous Fagus forest vegetation in the Southeast Europe. - Applied Vegetation Science 16(1): 131-147.

[23] McAleece, N., Lambshead, P. J. D., Paterson, G. L. J. (1997): Biodiversity Pro. Software Package. - The Natural History Museum, London. http://www.sams.ac.uk.

[24] Mueller-Dombois, D., Ellenberg, H. (1974): Aims and Methods of Vegetation Ecology. John Wiley and Sons, New York.

[25] Novaković-Vuković, M. (2015): Floristic characteristics of Austrian pine and Scots pine forests on serpentinite and serpentinite in western and central Serbia. - PhD Thesis, University of Belgrade, Faculty of Forestry, Belgrade, Serbia.

[26] Oberdorfer, E. (2001): Pflanzensociologische Excursionflora. - Verlag Eugen Ulmer, Stuttgart.

[27] Pavlović, Z. (1951): Vegetacija planine Zlatibor. - Zbornik radova 11, Institut za ekologiju i biogeografiju 2: 115-182.

[28] Pielou, E. C. (1975): Ecologocal Diversity. - Wiley, New York.

[29] Raunkiaer, C. (1934): The Life Forms of Plants and Statistical Plant Geography. Clarendon, Oxford.

[30] Riter-Studnička, H. (1963): Biljni pokrov na serpentinitima u Bosni. - Godišnjak Biološkog instituta Univerziteta Sarajevo 14(1-2): 91-204.

[31] Rubio-Moraga, A., Candel-Perez, D., Lucas-Borja, M. E., Tiscar, P. A., Vinegla, B., Linares, J. C., Gómez-Gómez, L., Ahrazem, O. (2012): Genetic diversity of Pinus nigra Arn. populations in southern Spain and northern Morocco revealed by inter-simple sequence repeat profiles. - International Journal of Molecular Sciences 13: 5645-5658.

[32] Stevanović, V. (1992): Floristička podela teritotije Srbije sa pregledom viših horiona i odgovarajućih flornih elemenata. - In: Sarić, M. (ed.) Flora Srbije I. Drugo izdanje. SANU, Beograd, pp. 37-49.

[33] Stevanović, V., Tan, K., Iatrou, G. (2003): Distribution of the endemic Balkan flora on serpentine, I.-obligate serpentine endemics. - Plant Systematics and Evolution 242: 149170.

[34] Tatić, B., Tomić, Z. (2006): Šume crnog i belog bora. - In: Škorić, D. (ed.) Vegetacija Srbije II2. Srpska akademija nauka i umetnosti, Beograd, pp. 127-154.

[35] Tichý, L. (2002): JUICE, software for vegetation classification. - Journal of Vegetation Science 13: 451-453.

[36] Tomić, Z., Rakonjac Lj. (2013): Forest Phytocenoses of Serbia. - Institute of Forestry and Faculty of Applied Ecology, Singidunum University, Belgrade.

[37] Van Der Maarel, E. (1979): Transformation of cover-abundance values in phytosociology and its effects on community similarity. Vegetatio 39(2): 97-114.

\section{APPENDIX}

Electronic Appendix 1. Phytocoenological table of the community of Black pine 